\title{
Severe Darier's disease in a 39-year-old patient
}

\section{Choroba Dariera o ciężkim przebiegu u 39-letniego pacjenta}

Dorota Kozłowska, Teresa Reduta, Joanna Bacharewicz-Szczerbicka, Iwona Flisiak

Department of Dermatology and Venereology, Medical University of Bialystok, Poland

Klinika Dermatologii i Wenerologii, Uniwersytet Medyczny w Białymstoku, Polska

Dermatol Rev/Przegl Dermatol 2018, 105, 738-745

DOI: https://doi.org//0.5 | |4/dr.2018.80843

\author{
CORRESPONDING AUTHOR/ \\ ADRES DO KORESPONDENCJI: \\ lek. med. Dorota Kozłowska \\ Klinika Dermatologii \\ i Wenerologii \\ Uniwersytet Medyczny \\ w Białymstoku \\ ul. Żurawia 14 \\ 15-540 Białystok, Polska \\ tel.: +48508182954 \\ e-mail: dorota.kozlowska@umb. \\ edu.pl
}

\begin{abstract}
Introduction. Darier's disease is a rare genodermatosis inherited in an autosomal dominant manner. Clinically, it manifests with hyperkeratotic papules in seborrhoeic and intertriginous areas as well as involvement of nail plates and mucous membranes. Patients may present with neuropsychiatric comorbidities.
\end{abstract}

Objective. To present a case of a patient with severe Darier's disease that was successfully treated with acitretin.

Case report. A 39-year-old man with a 24 year history of Darier's disease was admitted to the hospital because of an exacerbation of skin lesions. A year earlier he underwent an episode of severe depression. Because of signficant severity of skin lecions, acitretin was introduced with improvement.

Conclusions. Oral retinoids are the first line treatment against severe exacerbations of Darier's disease. Because of possible development of neuropsychiatric disorders, patients with Darier's disease should receive psychological and/or psychiatric consultations.

\section{STRESZCZENIE}

Wprowadzenie. Choroba Dariera jest rzadką genodermatozą dziedziczoną autosomalnie dominująco. Klinicznie objawia się występowaniem hiperkeratotycznych grudek w obrębie okolic łojotokowych i wyprzeniowych oraz zajęciem płytek paznokciowych i błon śluzowych. U chorych mogą występować zaburzenia neuropsychiatryczne.

Cel pracy. Przedstawienie przypadku pacjenta $\mathrm{z}$ chorobą Dariera o ciężkim przebiegu skutecznie leczonego acytretyną.

Opis przypadku. Trzydziestodziewięcioletni pacjent z wywiadem choroby Dariera od 15. roku życia został przyjęty do Kliniki z powodu zaostrzenia zmian skórnych. Przed rokiem przebył epizod ciężkiej depresji. Ze względu na bardzo duże zaawansowanie schorzenia do terapii włączono acytretynę z dobrym efektem.

Wnioski. Retinoidy doustne stanowią leczenie pierwszego wyboru ciężkich zaostrzeń choroby Dariera. Ze względu na możliwy rozwój zaburzeń neuropsychiatrycznych pacjenci z chorobą Dariera powinni być objęci stałą opieką psychologiczną i/lub psychiatryczną.

Key words: Darier's disease, genodermatosis, ATP2A2 gene.

Słowa kluczowe: choroba Dariera, genodermatoza, gen ATP2A2. 


\section{INTRODUCTION}

Darier's disease is a rare genodermatosis inherited in an autosomal dominant manner [1]. A mutation in the gene ATP2A2 located on the long arm of chromosome 12 (12q23-24) causes the disease. The gene is responsible for proper functioning of a calcium pump in endoplasmic reticulum (ATPase 2, a so-called SERCA 2) involved in an adhesion and epithelial cell differentiation process. The mutation in the gene ATP2A2 weakens connections between keratinocytes, causes acantholysis and abnormal keratinization of epidermis, what is of key importance in a pathomechanism of lesion development in Darier's disease [2]. The disease occurs in all ethnical groups with the frequency of $1 / 100,000$ population, equally frequently in both sexes. Its course is chronic with periods of exacerbations and remissions. In the majority of cases, first symptoms occur in pubescence or young adult age, however, a single case was described when the disease developed in a 66-year-old patient [1]. Clinically, the disease manifests itself with the appearance of red and brown hyperkeratotic papulae found within seborrhoeic areas, i.e. scalp, neck, sternal areas, posterior trunk, and intertriginous areas [3]. Moreover, keratinizing foci are observed within palms and soles, whereas papillary exanthemas are observed on dorsal surfaces of hands. The disease may involve pruritus with varying intensity, in case of maceration and cracking of epidermis. Lesions within oral mucous membranes are present in about $50 \%$ of patients, and take a form of whitish papulae found mainly on the palate and cheeks (cobblestone pattern) [4]. In the majority of patients lesions involve nail plates - presence of white and red longitudinal streaks is a pathognomonic sign. V-shaped defects in distal parts of nail plates and subungual hyperkeratosis are visible [5]. The disease may be exacerbated by exposure to solar radiation, overheating, high humidity, mechanical damage, stress, and during menstruation. Furthermore, cases of disease exacerbation after application of some drugs, interferon $\alpha$ (INF- $\alpha$ ) among others, have been described $[1,6]$.

The disease is diagnosed on the basis of clinical and histopathological pictures. Microscopic picture of skin lesions includes two characteristic phenomena - acantholysis and dyskeratosis of the epidermis, as well as presence of round bodies in the spinous layer and grains in the granular layer of the epidermis [7].

\section{OBJECTIVE}

To present a case of a patient with severe Darier's disease that was successfully treated with acitretin.

\section{CASE REPORT}

A 39-year-old male with Darier's disease in history since he was 15 year old reported to the Department

\section{WPROWADZENIE}

Choroba Dariera (Darier's disease, Darier-White disease, keratosis follicularis, dyskeratosis follicularis) należy do rzadkich genodermatoz dziedziczonych autosomalnie dominująco [1]. Podłożem choroby jest mutacja genu ATP2A2 zlokalizowanego na długim ramieniu chromosomu 12 (12q23-24). Wspomniany gen odpowiada za prawidłowe funkcjonowanie pompy wapniowej w retikulum endoplazmatycznym (ATP-azy 2, tzw. SERCA 2) zaangażowanej w proces adhezji i różnicowania komórek nabłonka. Mutacja w obrębie genu ATP2A2 powoduje osłabienie połączeń pomiędzy keratynocytami i akantolizę oraz nieprawidłowe rogowacenie naskórka, co ma istotne znaczenie w patomechanizmie powstawania zmian w chorobie Dariera [2]. Schorzenie występuje we wszystkich grupach etnicznych z częstością 1 na 100 000, równie często u obu płci. Charakteryzuje się przewlekłym przebiegiem, z okresami zaostrzeń i remisji. W większości przypadków pierwsze objawy pojawiają się w wieku pokwitania lub u młodych dorosłych, jednak opisano pojedynczy przypadek rozwoju choroby w wieku 66 lat [1]. Klinicznie schorzenie objawia się występowaniem czerwonobrązowych, hiperkeratotycznych grudek zlokalizowanych głównie w obrębie okolic łojotokowych, tj. owłosionej skóry głowy, szyi, mostka, tylnej część tułowia, a także w okolicach wyprzeniowych [3]. Ponadto na dłoniach i podeszwach stóp obserwuje się punktowe ogniska rogowacenia, a na grzbietowych powierzchniach rąk wykwity brodawkowate. Choroba może przebiegać $\mathrm{z}$ różnie nasilonym świądem, a w przypadku maceracji i pęknięć naskórka $\mathrm{z}$ bólem. Zmiany w obrębie błon śluzowych jamy ustnej obecne są u ok. 50\% pacjentów, mają postać białawych grudek umiejscowionych głównie na podniebieniu i policzkach (obraz kostki brukowej) [4]. U większości chorych zajęte są płytki paznokciowe, objawem patognomonicznym są biało-czerwone, podłużne pasma. Obserwuje się ubytki w kształcie litery V dystalnej części płytki paznokciowej oraz hiperkeratozę podpaznokciową [5]. Choroba może ulegać zaostrzeniu pod wpływem ekspozycji na promieniowanie słoneczne, przegrzania, dużej wilgotności, urazów mechanicznych, stresu, a także w okresie menstruacji. Opisywano przypadki zaostrzeń choroby po zastosowaniu niektórych leków, m.in. interferonu $\alpha$ (INF- $\alpha)[1,6]$.

Rozpoznanie choroby ustala się na podstawie obrazu klinicznego oraz histopatologicznego. Charakterystyczne są występowanie w obrazie mikroskopowym zmian skórnych dwóch zjawisk - akantolizy i dyskeratozy naskórka, a także obecność ciałek okrągłych w warstwie kolczystej naskórka oraz ziaren w warstwie ziarnistej [7].

\section{CEL PRACY}

Przedstawienie przypadku pacjenta z chorobą Dariera o ciężkim przebiegu skutecznie leczonego acytretyną. 
of Dermatology and Venereology in order to treat his skin lesions that became exacerbated within the previous 2 years. In the past he was hospitalized twice at the Department due to the disease exacerbation. In 2012-2016 the patient was treated with acitretin in the dose of 20-30 mg/day with good therapeutic results. After 4 years he discontinued the treatment, but skin lesions were continually progressing and made it impossible for him to function within the society without problems. During the 2-year break in his treatment, the patient underwent an episode of severe depression, due to which he was hospitalized at the Department of Psychiatry. Mild Darier's disease was confirmed in his mother, sister, brother, nephew and niece.

Upon admission to the Department the following were observed within skin of his entire body: widespread hyperkeratotic papulae and built-up callous masses with present oozing skin cracks and rips. Exanthemas were especially intensified within back skin, and within areas of armpits, groins and scrotal sac skin (figs. 1, 2). There were widespread hyperkeratotic foci within palms and soles, finger nail plates showed lesions in a form of subungual hyperkeratosis and V-shaped defects in distal parts of nail plates (fig. 3). Whitish papulae were observed within oral mucous membranes.

Laboratory tests revealed abnormal rise in acutephase parameters, ASO, and anaemia. Due to the fact that the patient reported abdominal pain and

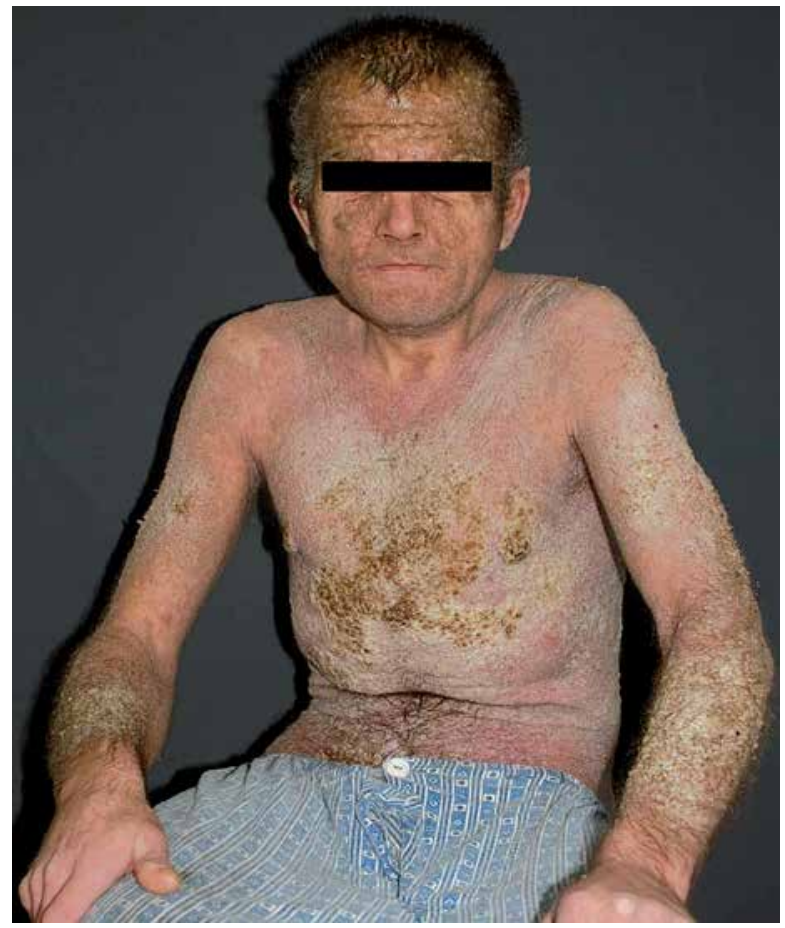

Figure I. Numerous hyperkeratotic papules in the skin of face, thorax, abdomen and upper extremities

Rycina I. Liczne hiperkeratotyczne grudki w obrębie skóry twarzy, klatki piersiowej, brzucha oraz kończyn górnych

\section{OPIS PRZYPADKU}

Trzydziestodziewięcioletni mężczyzna z wywiadem choroby Dariera od 15. roku życia zgłosił się do Kliniki Dermatologii i Wenerologii w celu leczenia zmian skórnych, które uległy zaostrzeniu w czasie ostatnich 2 lat. W przeszłości był dwukrotnie hospitalizowany w Klinice z powodu zaostrzeń choroby. W latach 2012-2016 pacjent przyjmował acytretynę w dawce 20-30 mg/dobę z dobrym efektem terapeutycznym. Po 4 latach zaprzestał leczenia, zmiany skórne ulegały ciągłej progresji, co uniemożliwiało prawidłowe funkcjonowanie w społeczeństwie. Podczas 2-letniej przerwy w terapii u pacjenta wystąpiła ciężka depresja, z powodu której był hospitalizowany w Klinice Psychiatrii. Chorobę Dariera o łagodnym przebiegu potwierdzono u matki, siostry, brata, siostrzeńca oraz siostrzenicy chorego.

Przy przyjęciu do Kliniki na całej skórze obserwowano rozległe zmiany w postaci hiperkeratotycznych grudek oraz nawarstwionych zrogowaciałych mas z obecnością sączących szczelin i pęknięć skóry. Wykwity były szczególnie nasilone na plecach, a także w okolicach pach i pachwin oraz na skórze moszny (ryc. 1, 2). Na skórze powierzchni dłoniowej rąk oraz na podeszwach stóp stwierdzono rozległe ogniska hiperkeratozy, w obrębie paznokci rąk obserwowano hiperkeratozę podpaznokciową oraz ubytki w kształcie litery $\mathrm{V}$ dotyczące

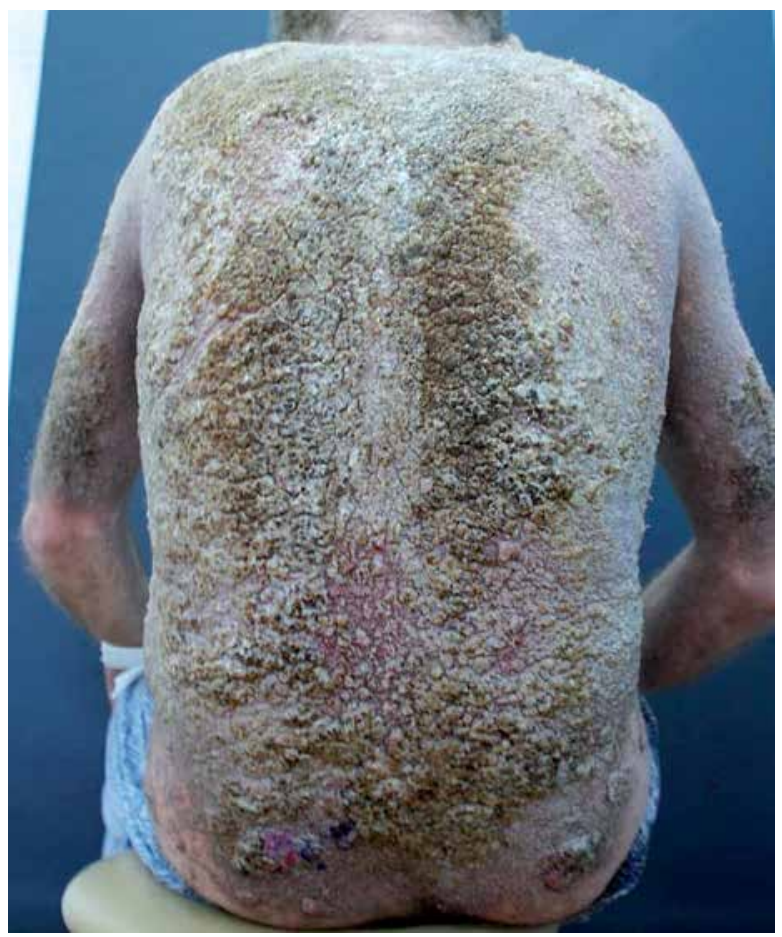

Figure 2. Stratified keratinized masses with the presence of leaking fissures and cracks of the back's skin

Rycina 2. Nawarstwione hiperkeratotyczne masy z obecnością pęknięć i szczelin w obrębie skóry pleców 

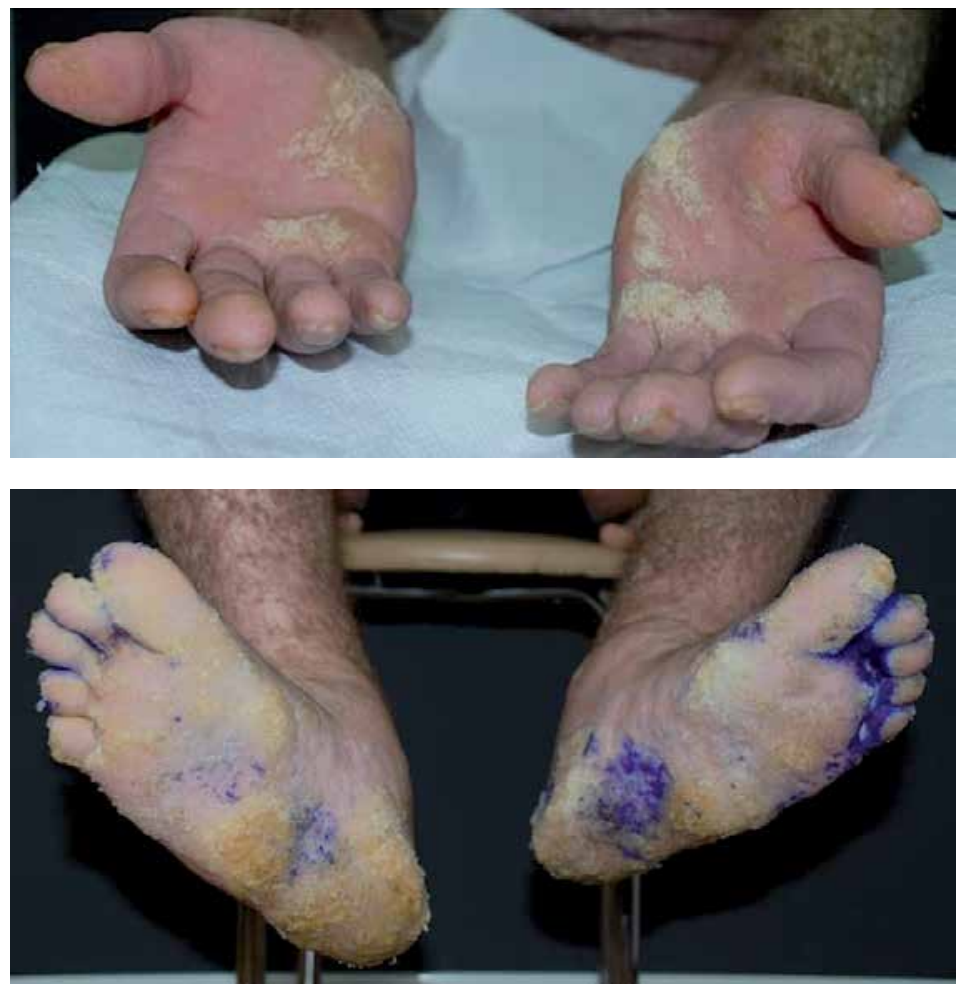

Figure 3. Extensive of hyperkeratosis in the palms and soles

Rycina 3. Rozległe ogniska hiperkeratozy w obrębie dłoni i podeszew stóp

tenderness in the epigastric region upon physical examination, activity of pancreatic enzymes in serum and urine was estimated; it exceeded the normal range significantly. An abdominal cavity ultrasound (normal) and gastroscopy were performed; the latter revealed chronic erosive gastritis. The patient had a gastroenterological consultation, and acute pancreatitis was ruled out. Other parameters evaluating liver function, kidney parameters, electrolytes, lipid metabolism, and chest X-ray were normal. Due to signs of the secondary infection within skin lesions, a bacteriological test was performed - a Proteus mirabilis strain was cultured from the scrotal sac skin erosions. As Darier's disease was confirmed in histopathological examination in 2012, it was decided not to perform a skin biopsy again.

General treatment included acitretin at an initial dose of $30 \mathrm{mg} /$ day, however, due to a massive ankle joint oedema the dose was reduced to $20 \mathrm{mg}$ / day after a week. The following were included: an antibiotic therapy according to the antibiogram, antimycotic preparations, proton pump inhibitors, pancreatin, and relaxants. Topical treatment included keratolytic, antiseptic, and antibacterial preparations, as well as $\mathrm{KMnO}_{4}$ baths. After a 2-week hospitalization period a considerable improvement in focal condition was achieved: callous masses were significantly smaller, hyperkeratotic papulae were reduced, and the patient's well-being was improved (figs. 4,5 ). The pa- dystalnej części płytki paznokciowej (ryc. 3). Na błonie śluzowej jamy ustnej obserwowano białawe grudki.

$\mathrm{W}$ badaniach laboratoryjnych $\mathrm{z}$ odchyleń stwierdzono podwyższone stężenie laboratoryjnych wykładników stanu zapalnego, podwyższone ASO oraz niedokrwistość. Z powodu zgłaszanych przez chorego dolegliwości bólowych brzucha i tkliwości w obrębie nadbrzusza $w$ badaniu przedmiotowym oznaczono w surowicy i moczu aktywność enzymów trzustkowych, która znacznie przekraczała granice normy. Wykonano badanie ultrasonograficzne jamy brzusznej (bez odchyleń) oraz gastroskopię, która uwidoczniła przewlekłe nadżerkowe zapalenie błony śluzowej żołądka. Chorego konsultowano gastroenterologicznie, wykluczono ostre zapalenie trzustki. Pozostałe parametry oceniające funkcje wątroby, parametry nerkowe, elektrolity, gospodarkę lipidową oraz badanie rentgenograficzne klatki piersiowej były prawidłowe. Z powodu cech wtórnej infekcji w obrębie zmian skórnych wykonano badanie bakteriologiczne - z nadżerek skóry moszny wyhodowano szczep Proteus mirabilis. Ze względu na potwierdzenie w 2012 r. choroby Dariera za pomocą badania histopatologicznego obecnie odstąpiono od ponownego pobierania wycinka skóry.

W leczeniu ogólnym zastosowano acytretynę $\mathrm{w}$ początkowej dawce $30 \mathrm{mg} /$ dobę, jednak z powodu wystąpienia masywnego obrzęku stawów skokowych po tygodniu dawkę zredukowano do $20 \mathrm{mg} /$ dobę. Dołączono antybiotykoterapię zgodnie z anty- 


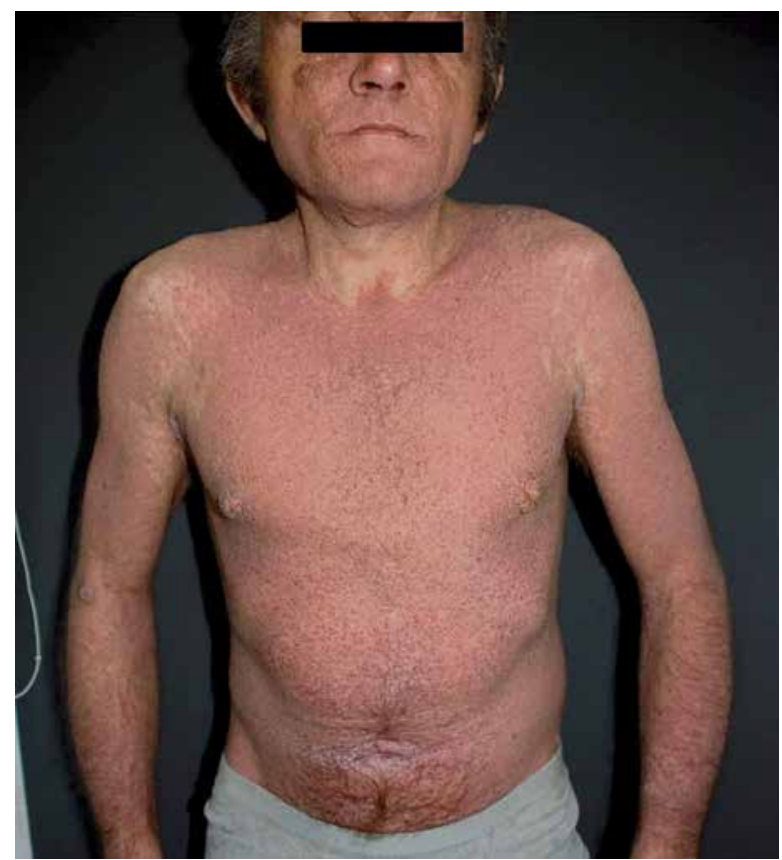

Figure 4. Patient after 2 weeks of treatment with acitretin. Improvement of the local condition of the skin - reduction of hyperkeratotic papules

Rycina 4. Pacjent po 2 tygodniach leczenia acytretyną. Poprawa stanu miejscowego - znaczna redukcja hiperkeratotycznych grudek

tient continues the acitretin therapy in the existing dose. So far, neither disease exacerbations nor drug adverse reactions have been observed, and the results of laboratory tests evaluating liver and pancreas functions as well as lipid metabolism parameters are within normal limits. The patient remains under strict supervision of Mental Health Clinic.

\section{DISCUSSION}

Darier's disease was described for the first time in 1886 by Prince Marrow, and 3 year later, by Darier and White independently. Then, in 1917 Prindiville and Stern described a case of dyskeratosis follicularis involving mucous membranes for the first time [2,3].

The disease belongs to rare genodermatoses inherited in an autosomal dominant manner with a complete gene penetration and varying intensity of symptoms, even within members of one family, what was observed in the case of the presented patient [6].

A relationship between Darier's disease and co-occurrence of neuropsychiatric disorders was described. The patients are at risk of an increased incidence of depression, suicidal thoughts and tendencies, bipolar disorders, psychoses, and mental impairment. Co-occurrence of the above disorders is probably caused by an ATP2A2 gene mutation, which undergoes expression in skin and brain $[8,9]$. According to GordonSmith et al., who examined 100 individual patients

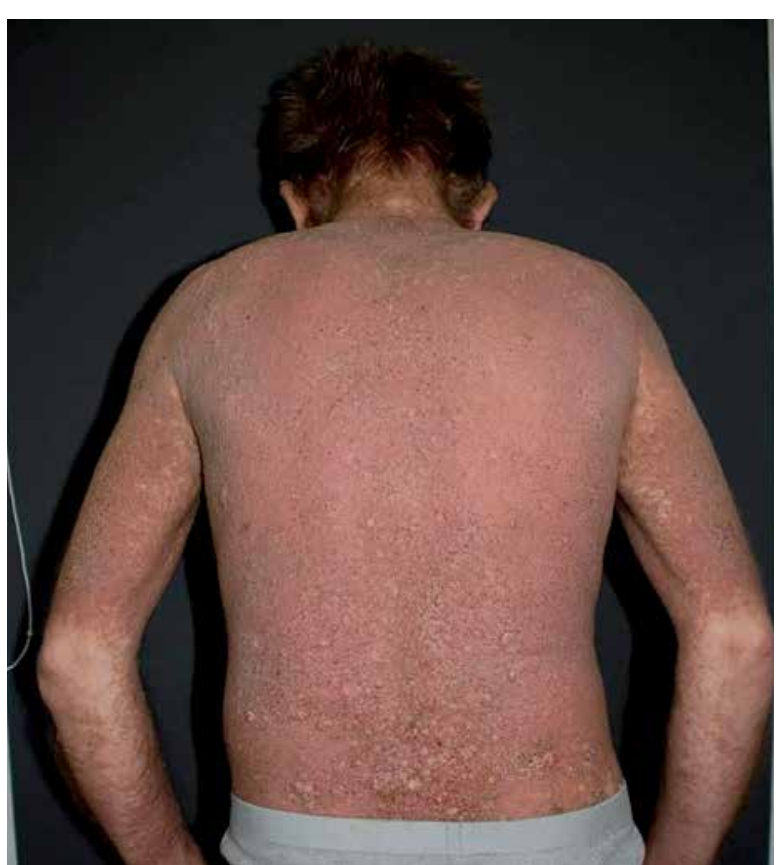

Figure 5. Reduction of stratified, hyperkeratotic masses in the back's skin after 2 weeks of treatment

Rycina 5. Redukcja nawarstwionych, zrogowaciałych mas w obrębie skóry pleców po 2 tygodniach leczenia

biogramem, preparaty przeciwgrzybicze, inhibitory pompy protonowej, pankreatynę oraz leki rozkurczowe. W leczeniu miejscowym włączono preparaty keratolityczne, odkażające i przeciwbakteryjne oraz kąpiele w roztworze $\mathrm{KMnO}_{4}$. Po 2-tygodniowej hospitalizacji stwierdzono znaczną poprawę stanu miejscowego (znaczne zmniejszenie mas rogowych i redukcję hiperkeratotycznych grudek) oraz poprawę samopoczucia chorego (ryc. 4, 5). Pacjent kontynuuje terapię acytretyną w dotychczasowej dawce. Do tej pory nie obserwowano zaostrzeń choroby, działań niepożądanych leku, a wyniki badań laboratoryjnych oceniających funkcje wątroby, trzustki oraz parametry gospodarki lipidowej mieszczą się w granicach normy. Pacjent jest pod ścisłą kontrolą poradni zdrowia psychicznego.

\section{OMÓWIENIE}

Choroba Dariera po raz pierwszy została opisana w 1886 r. przez Prince'a Marrowa, 3 lata później, niezależnie opisali ją Darier i White. W 1917 r. Prindiville i Stern po raz pierwszy opisali przypadek $d y s-$ keratosis follicularis z zajęciem błon śluzowych $[2,3]$.

Schorzenie należy do rzadkich genodermatoz dziedziczonych autosomalnie dominująco z całkowitą penetracją genu i różnym nasileniem objawów, nawet wśród członków jednej rodziny, co obserwowano w przypadku prezentowanego pacjenta [6]. 
with Darier's disease, psychiatric illnesses diagnosed in the analysed patients were not psychological reactions to skin lesions, but disorders independent of skin exanthema. The presented patient was diagnosed with depression that required hospitalization.

Darier's disease is a disease that mainly involves skin, mucous membranes and nails, however, sometimes the organ of vision may be involved. Ocular symptoms occur rarely and cover spot damage of epithelium of the cornea with photophobia, corneal ulceration, conjunctival keratinisation, and an increased tendency towards recurring herpetiform corneitis. Singular cases of cataracts and retinal ablation were described $[10,11]$.

Diagnosing Darier's disease is not difficult due to its rather typical clinical and histopathological picture. Entities that may imitate dyskeratosis follicularis, with regard to clinical and microscopical similarities, include: Grover's disease, Hailey-Hailey disease, seborrhoeic dermatitis, and lichen planus. In case of linear Darier's disease, differential diagnostics includes the following among others: inflammatory linear verrucous epidermal naevus (ILVEN) and herpes zoster.

As there is a possibility of developing a number of disorders, patients should remain under continual supervision of dermatologists, psychiatrists, and ophthalmologists. Dermatological treatment of Darie$r^{\prime}$ s disease depends on the extent of skin lesions. In mild cases, keratinization may be decreased by local keratolytic preparations and retinoids (adapalene, tazarotene). Satisfactory results are observed after the application of 3\% diclofenac gel, especially in patients who do not respond to other treatment methods $[12,13]$. An inflammation within skin lesions may be alleviated by applying glucocorticosteroid preparations with low or medium strength. In cases of severe exacerbation, oral retinoids, i.e. acitretin, isotretinoin and alitretinoin, may bring good therapeutic results. In the case of the presented patient, a repeated acitretin therapy was necessary to control the topical condition. In spite of the occurrence of adverse reaction in a form of joint oedema, it was decided to continue the therapy with a decreased dose. Taking into account the adverse reactions caused by retinoids, a proper classification of patients for the treatment is recommended. Considering the activity of teratogenic retinoids, it regards especially women at reproductive age. An influence of acitretin on development of mental disorder has not been expressly specified, but there exist reports of cases when depression occurred in patients treated with acitretin [14]. In the case of the described patients, an episode of depression occurred when the treatment was discontinued and when skin lesions intensified; however, after his clinical condition improved with application of acitretin therapy, his mental condition improved, too. Never-
Opisywano związek między chorobą Dariera a współwystępowaniem zaburzeń neuropsychiatrycznych. Wśród pacjentów stwierdza się zwiększoną zapadalność na depresję, myśli i skłonności samobójcze, chorobę dwubiegunową, psychozy, a także upośledzenie umysłowe. Za współwystępowanie powyższych zaburzeń prawdopodobnie odpowiada mutacja genu ATP2A2, który ulega ekspresji zarówno w skórze, jak i mózgu [8, 9]. Według Gordona-Smitha i wsp., którzy przebadali 100 pacjentów z chorobą Dariera, schorzenia psychiatryczne zdiagnozowane $\mathrm{u}$ badanych nie były reakcją psychologiczną na zmiany skórne, lecz zaburzeniami niezależnymi od wykwitów skórnych. U przedstawionego pacjenta stwierdzono depresję wymagającą hospitalizacji.

W przebiegu choroby Dariera zajęta jest głównie skóra, błony śluzowe i paznokcie, jednak niekiedy może dojść do zajęcia narządu wzroku. Objawy oczne występują rzadko i obejmują punktowe uszkodzenia nabłonka rogówki przebiegające ze światłowstrętem, owrzodzenia rogówki, rogowacenie spojówki, a także zwiększoną skłonność do nawracających opryszczkowatych zapaleń rogówki. Opisano pojedyncze przypadki wystąpienia zaćmy i odwarstwienia siatkówki $[10,11]$.

Rozpoznanie choroby Dariera ze względu na typowy obraz kliniczny i histopatologiczny nie sprawia trudności. Wśród jednostek, które mogą imitować dyskeratosis follicularis ze względu na podobieństwo zarówno cech klinicznych, jak i mikroskopowych, należy brać pod uwagę chorobę Grovera, łagodną pęcherzycę Haileya-Haileya, łojotokowe zapalenie skóry, a także liszaj płaski. W przypadku wariantu linijnego choroby diagnostyka różnicowa obejmuje m.in. zapalne linijne brodawkowate znamię naskórkowe (inflammatory linear verrucous epidermal naevus - ILVEN) i półpasiec.

Ze względu na możliwość rozwoju wielu zaburzeń pacjenci powinni znajdować się pod stałą opieką lekarzy dermatologów, psychiatrów i okulistów. Leczenie dermatologiczne choroby Dariera zależy od rozległości zmian skórnych. W przypadku postaci łagodnych choroby zmniejszenie rogowacenia uzyskuje się za pomocą miejscowych preparatów keratolitycznych oraz retinoidów (adapalen, tazaroten). Zadowalające efekty obserwuje się po zastosowaniu 3\% diklofenaku w żelu, zwłaszcza u pacjentów niereagujących na inne metody leczenia $[12,13]$. Stan zapalny w obrębie zmienionej chorobowo skóry mogą łagodzić preparaty glikokortykosteroidowe o małej lub średniej mocy. W przypadku ciężkich zaostrzeń dobre efekty terapeutyczne można uzyskać przy zastosowaniu doustnych retinoidów, takich jak acytretyna, izotretynoina oraz alitretynoina. U opisanego pacjenta ponowna terapia acytretyną była niezbędna do opanowania stanu miejscowego. Pomimo wy- 
theless, the patient requires a systematic psychiatric care. An administration of oral doxycycline may be a good therapeutic option due to its safety profile and antibacterial activities, especially for patients for whom retinoids are contraindicated [7]. In all cases, it is recommended to observe hygiene procedures in order to avoid secondary bacterial and mycotic superinfections.

\section{CONCLUSIONS}

Considering a possible severe course of the disease that may decrease patients' quality of life, and co-occurring neuropsychiatric disorders, patients should remain under a permanent dermatological, psychological and psychiatric care. Informing patients about the necessity to avoid exacerbating factors is an important part of preventing disease exacerbations. Since the disease is genetic, it is significant to educate patients and refer them for genetic consultations in order to explain the risk of transmitting the mutation onto the offspring.

\section{CONFLICT OF INTEREST}

The authors declare no conflict of interest. stąpienia działań niepożądanych w postaci obrzęku stawów zdecydowano o kontynuowaniu terapii w mniejszej dawce. Ze względu na możliwe działania niepożądane retinoidów wskazana jest odpowiednia kwalifikacja chorych do leczenia. Dotyczy to zwłaszcza kobiet $\mathrm{w}$ okresie reprodukcyjnym w związku $\mathrm{z}$ działaniem teratogennym retinoidów. Wpływ acytretyny na rozwój zaburzeń psychicznych nie został jednoznacznie określony, lecz znane są doniesienia o przypadkach występowania depresji u chorych leczonych acytretyną [14]. W przypadku opisanego pacjenta depresja wystąpiła po zaprzestaniu leczenia, w trakcie nasilenia zmian skórnych, natomiast po uzyskaniu poprawy klinicznej w wyniku leczenia acytretyną stan psychiczny chorego znacznie się poprawił. Pacjent wymaga jednak systematycznej opieki psychiatrycznej. Stosowanie doksycykliny doustnie ze względu na profil bezpieczeństwa i działanie antybakteryjne może być dobrą opcją terapeutyczną, zwłaszcza u pacjentów z przeciwwskazaniami do stosowania retinoidów [7]. We wszystkich przypadkach wskazane jest także przestrzeganie higieny w celu profilaktyki wtórnych nadkażeń bakteryjnych i grzybiczych.

\section{WNIOSKI}

Ze względu na możliwy ciężki przebieg choroby, który obniża jakość życia, a także potencjalne współwystępowanie zaburzeń neuropsychiatrycznych pacjenci powinni być objęci stałą opieką dermatologiczną, a także psychologiczną i psychiatryczną. Ważnym elementem profilaktyki zaostrzeń choroby jest poinformowanie pacjentów o konieczności unikania czynników zaostrzających. Ze względu na podłoże genetyczne choroby ważna jest edukacja pacjenta oraz poradnictwo genetyczne w celu wyjaśnienia ryzyka przeniesienia mutacji na potomstwo.

\section{KONFLIKT INTERESÓW}

Autorzy nie zgłaszają konfliktu interesów.

\section{References}

\section{Piśmiennictwo}

1. Karagiannidis I., Brunner M., Zouboulis C.: Exacerbation of Darier disease under interferon-alpha-2a therapy with clinical signs of lichen nitidus. Case Rep Dermatol 2016, 8, 218-223.

2. Linder D., Marinello E., Donisi P.: Inflamammary dermatitis: a case of localized late-onset Darier's disease. Case Rep Dermatol 2016, 8, 189-192.

3. Dharman S, Arvind M.: Darier's disease: oral, general and histopathological features in a 7 year old child. J Indian Soc Pedod Prev Dent 2016, 34, 177-179.

4. Sławińska M., Sobjanek M., Biernat W., Sejda A., Nowicki R.: Localized Darier's disease - case report. Forum Dermatologicum 2016, 2, 123-125.

5. Suryawanshi H., Dhobley A., Sharma A., Kumar P.: Darier disease: a rare genodermatosis. J Oral Maxillofac Pathol $2017,21,321$.

6. Węgłowska J., Rajkowska-Strojs K., Chrzanowska K.: Unilateral Darier's disease - case report. Dermatol Rev 2017, 104, 555-560. 
7. Sfecci A., Orion C., Darrieux L.: Extensive Darier disease successfully treated with doxycycline monotherapy. Case Rep Dermatol 2015, 7, 311-315.

8. Gordon-Smith K., Jones L.A., Burge S.M., Munro C.S., Tavadia S., Craddock N.: The neuropsychiatric phenotype in Darier disease. Br J Dermatol 2010, 163, 515-522.

9. Yang J., Lopes R., Pereira M., Tebcherani A.J., Pires M.C.: Severe Darier's disease in a psychiatric patient. An Bras Dermatol 2015, 90, 66-68.

10. Kanakpur S., Caculo D.: Rare ocular manifestations in keratosis follicularis (Darier-White disease). Indian J Ophthalmol 2017, $65,874-876$.

11. Radia M., Gilhooley M.J., Panos C., Claoue C.: Recurrent presumed Herpes simplex keratitis and episcleritis in keratosis follicularis (Darier's disease). BMJ Case Rep 2015, pii: bcr2015210772.

12. Santos-Alarcon S., Sanchis-Sanchez C., Mateu-Puchades A.: Diclofenac sodium 3\% gel for Darier's disease treatment. Dermatol Online J 2016, 22, pii: 13030/qt1mz2m9ks.

13. Millán-Parrilla F., Rodrigo-Nicolás B., Molés-Poveda P., Armengot-Carbo M., Quecedo-Estebanez E., Gimeno-Carpio E.: Improvement of Darier disease with diclofenac sodium 3\% gel. J Am Acad Dermatol 2014, 70, 89-90.

14. Hayes J., Koo J.: Depression and acitretin: a true association or a class labelling? J Drugs Dermatol 2011, 10, 409-412.

Received: 19.06 .2018

Accepted: 24.08 .2018

Otrzymano: $19.06 .2018 \mathrm{r}$.

Zaakceptowano: $24.08 .2018 \mathrm{r}$.

How to cite this article

Kozłowska D., Reduta T., Bacharewicz-Szczerbicka J., Flisiak I.: Severe Darier's disease in a 39-year-old patient. Dermatol Rev/ Przegl Dermatol 2018, 105, 738-745. DOI: https://doi.org/10.5114/dr.2018.80843. 